ISSN No. 0974-035X

An indexed refereed \& peer-reviewed journal of higher education

Towards Excellence

UGC-HUMAN RESOURCE DEVELOPMENT CENTRE

Gujarat University, Ahmedabad-380009, Gujarat, India

\title{
SRINGARA AND KARUNA RASAS IN THE SECRET OF THE NAGAS
}

\section{Prof. Jagdish S. Joshi \\ Mr. Saurabh Vaishnav}

\begin{abstract}
:
Rasa is the emotional element in the theme or plot which falls into an organised pattern. Rasa emotionally connects the observer to a work of art. The more emotional connection of the reader to a work of art, the better the production of rasa. Rasa is an experience first felt by the creator of the art, and secondly the experience of the reader who receives the art. The creator seeks a medium to express his feelings. The reader or observer then obtains the same emotion through the medium that the creator selected and hence experiences the emotion felt by the creator. Thus, the feeling of 'rasa' which is created by the creator is then re-created by the reader. The extent the reader experiences the emotion which was earlier felt by the creator depends on the aesthetic sense the reader possesses and the intelligence of the creator in producing it. Rasa has been a prolific theory contributed by Bharata Muni in the field of Indian Aesthetics. The paper analyses the dominance of Sringara and Karuna rasas in The Secret of the Nagas.
\end{abstract}

Key words: Rasa, Sringara, Karuna, aesthetic, Nagas

\section{Introduction:}

The Secret of the Nagas is the second novel in the Shiva trilogy. It was published in 2011. The Secret of the Nagas details the journey of Shiva after the war between the Suryavanshis and Chandravanshis. Shiva is devastated at the 
Towards Excellence: An Indexed, Refereed \& Peer Reviewed Journal of Higher Education / Prof. Jagdish Joshi \& Mr. Saurabh Vaishnav/ Page 98-116

apparent death of Brahaspati. And he vows to kill the Naga who murdered Brahaspati. The Rasa theory has been propagated by Bharata Muni in his seminal book Natyashastra. Bharata Muni has discussed about the evocation and propagation of eight rasas. The present research paper analyses the presence of Sringara and Karuna rasas in the novel.

According to Bharata Muni, sringara rasa can be divided into two categories: a) Sambhoga sringara or love in union, and b) Vipralambha sringara or love in separation. The effects (anubhavas) of sambhoga sringara are skilful use of eyes, frowning, side-glances, flirtatious movements, gentle body movements and soft speech. The effects of vipralambha sringara are dejectedness and indifference to worldly joys, languor, apprehension, jealousy, weariness, anxiety and worry, yearning, drowsiness, sleep, dream, feigned anger, illness, insanity, forgetfulness, sluggishness, death and other conditions.

Sringara Rasa is fructified by the activities like a blossoming season, garland, ornaments, melodious music, poetry, and near and dear ones, visiting parks and gardens, etc. Sringara Rasa is presented through graceful movements of the body parts accompanied by innocent smiles, heart-warming words, strength, jubilant expressions, tranquil eyes, beaming face etc. Love is not just rati, the amorous feeling. There can be love between brother and a sister, a mother and its kid, between siblings, between friends, between students and teacher and of course love towards God. All individuals aspire to live with a sense of beauty and love.

The dominant emotion or the sthayibhava in karuna rasa is soka or sorrow. Its presentation on the stage is through the following anubhavas, viz. teary eyes, mourning, dehydrated throat, paleness of the face, drooping of the limbs, gasping of 
Towards Excellence: An Indexed, Refereed \& Peer Reviewed Journal of Higher Education / Prof. Jagdish Joshi \& Mr. Saurabh Vaishnav/ Page 98-116

breath, loss of memory and other similar things. The vyabhicari bhavas of karuna rasa are dejectedness, in difference, languor, anxiety, yearning excited state, illusion, loss of sense, sadness, ailments, lethargy, sluggishness, epileptic loss of memory, fear, death, paralysis, shivering, and the kindred feelings. It is to be presented on the stage through sighs, lamentations, loss of sense, weeping bitterly and other similar gestures.

\section{Sringara Rasa in The Secret of the Nagas}

Parvateshwar looked up. Anandmayi was lying on her stomach next to a picture window overlooking the royal gardens. Kanini, her masseuse, was working her magic on the princess' exotic and supple body. Anandmayi only had one piece of cloth draped loosely from her lower back to her upper thighs. The rest of her, a feast for his eyes. "Beautiful view, isn't it?" asked Anandmayi. (Tripathi 24)

The interactions between Parvateshwar and Anandmayi, the daughter of King Dilipa of Swadweep have a tone of dual meanings. Anandmayi was trying to seduce Parvateshwar in whichever ways she could. Her body language, her tone, her sex appeal, her words were always laced with sexual connotations. Parvateshwar was someone who followed the rules and regulations diligently. He was someone who has always observed the legal codes and conducts.

Anandmayi was mightily impressed by the devotion of Parvateshwar towards his duties. Since the time that she was introduced in the novel, she tried her best to unnerve and seduce Parvateshwar with her charisma. During this passage of the novel, Parvateshwar had come to ask Anandmayi of any specific request that she had as the whole contingent was travelling to Kashi. Anandmayi used to have 
Towards Excellence: An Indexed, Refereed \& Peer Reviewed Journal of Higher Education / Prof. Jagdish Joshi \& Mr. Saurabh Vaishnav/ Page 98-116

strange requirements. As Parvateshwar was looking over the requirement list and arrangements of the contingent he had come to ask Anandmayi if she had any requirements.

Anandmayi was getting herself massaged by her masseuse. She was in the least of clothes. She was bare backed. The only cloth that was covering her was a small piece of cloth covering her lower back to her upper thighs. Anandmayi was looking out at the open fields through the window. The view was stunning. The moment Parvateshwar entered, Anandmayi asked him an insinuating question about the view being beautiful. The question itself has dual meanings.

While the obvious inference of the question means that the natural view is beautiful. However the sly inference of the question could be about her own body. Anandmayi was projecting her sexuality in a sly manner. Parvateshwar was too shy and coy to be able to differentiate the finer differences of the question. He seemed to be succumbing to the sexual invocation that Anandmayi seemed to draw him into.

Anandmayi was sexually teasing Parvateshwar. According to Cindy Meston and Lucia O'Sullivan, "Sexual teasing is a form of provocation characterized by the promise of sexual contact followed by withdrawal. The intention is to frustrate or cause tension in the target and incorporates some use of power of one person over another" (531). Clearly Anandmayi was making use of her body and showcasing it to incite Parvateshwar. She did not intend to humiliate Parvateshwar, but she used such deceptions in order to make Parvateshwar fall for her.

Such use of language, such slyness, sexual innuendos, toying with the other gender, coyness, shyness, sexual inferences, inciting the libido are all the different elements related to Sringara rasa. Sex is also a form of love. Not only love but 
Towards Excellence: An Indexed, Refereed \& Peer Reviewed Journal of Higher Education / Prof. Jagdish Joshi \& Mr. Saurabh Vaishnav/ Page 98-116

infatuation and sensuality are also a part of Sringara rasa. And in this scene the dominance of Sringara rasa is observed.

"'Mmm", mumbled Shiva as Sati softly kissed him awake. He cupped her face gently. "Are my eyes deceiving me or are you getting more beautiful every day?"” (67). Shiva and Sati were mesmerized by the beauty of Kashi. They had not encountered a more beautiful and tranquil place than Kashi. Sati was pregnant and soon she would be delivering their child. They decided that Sati would give birth to their child in Kashi. Both of them were deeply in love with each other.

In this instance, Sati woke Shiva up by gently kissing him. Shiva was slowly and gradually waking up and admitting the beauty of Sati. He remarked that Sati was getting beautiful every day. The remark of Shiva signifies Sringara rasa. Shiva was a very supportive and caring husband and he had made sure that all arrangements and preparations were done for the birth of their child. During the time of pregnancy, constant love, comfort and warmth are needed for any female. The warmth and comfort helps a female during the stressful time of delivery.

Shiva who had several tasks at hand never failed to provide warmth and comfort to Sati. He constantly admires her warrior like qualities as well as her beauty. He always made Sati comfortable by diffusing any serious situation into humour. Sati too was always comforting and sharing the warmth that she received from Shiva. Both of them were acting as an ideal couple in the novel. The remark made by Shiva is bound to make any woman special and beautiful. Such compliments are needed to sustain a healthy, emotionally balanced marital life.

According to "The Psychology behind Love and Romance", 
Towards Excellence: An Indexed, Refereed \& Peer Reviewed Journal of Higher Education / Prof. Jagdish Joshi \& Mr. Saurabh Vaishnav/ Page 98-116

A person in love sees the world through the lens of love and most everything is tolerable and everything their partner does is delightful," Romantic love evolves when one feels a sense of interdependence, attachment, and that their psychological needs are being met. Falling in love is associated with increased energy, narrowing of mental focus, sometimes sweaty palms, lightheadedness, racing heart, and a lot of positive feelings.

By sharing such beautiful moments of love, caring and warmth, Tripathi in this scene of the novel showcased the presence of Sringara rasa. The love between Shiva and Sati had moved to another dimension. Both of them cared about one another and also enjoyed the simplest pleasures that life had to offer. All these components reflect the presence of Sringara rasa in this passage of the novel.

"Sati looked up and kissed Shiva again. "Just find a path to the Nagas and come back to me soon." "I certainly will, my love"” (152). Shiva was traumatized to find out that the medicine handed over to him by the Vasudeva pandit belonged to Nagas. Shiva was diligent to take revenge on the Nagas for murdering his best friend Brahaspati. And now when he discovered the fact that the Nagas supplied the medicine to the Vasudeva Pandit, Shiva wanted to find out the real truth of the Nagas.

Shiva was soon going on his mission to find out about the Nagas. He had come to bid farewell to his wife and his infant son. Even in the midst of revenge and vengeance, the scene reflects Sringara rasa. The eternal love between Shiva and Sati is faithfully represented here. Sati knew the desperation Shiva was in to find out the truth. She urged Shiva to come back safely after finding the truth about the Nagas. 
Towards Excellence: An Indexed, Refereed \& Peer Reviewed Journal of Higher Education / Prof. Jagdish Joshi \& Mr. Saurabh Vaishnav/ Page 98-116

According to Robert Sternberg, "The triangular theory of love holds that love can be understood in terms of three components that together can be viewed as forming the vertices of a triangle. These three components are intimacy, passion, and decision/commitment" (119). Intimacy encompasses feelings of attachment, closeness, connectedness, and bond. Passion encompasses drives connected to both limerence and sexual attraction. Commitment encompasses the decision to remain with another, and in the long term, the shared achievements and plans made with that other person.

The scene presents the undying love between a couple. Both Sati and Shiva cared about each other. They valued the company of one another. Their life was prioritized by each other's commitments. Shiva's destiny was beyond the family responsibilities. Sati understood it and she willingly let her husband go on the path to search the truth. However the little insecurities made Sati ask Shiva to come back as soon as he found the truth. This scene is a representative of Sringara rasa.

Ganesh's tears broke out in a stronger flood. He wrapped his arms around his mother and whispered that most magical words. "Maa ...." Sati started crying again. "My son. My son." Ganesh cried like the sheltered little child he had always wanted to be. He was safe. Safe at last. Safe in his loving mother's arms. (238)

Ganesh and his aunt Kali had just saved the troop of Sati which was attacked by the lions. Ganesh had managed to save Sati by plunging forward ahead of the fearsome liger. Soon Kali revealed the truth to Sati that she was her elder sister and that Ganesh was the son of Sati. This broke the dam of emotions in both Sati as well 
Towards Excellence: An Indexed, Refereed \& Peer Reviewed Journal of Higher Education / Prof. Jagdish Joshi \& Mr. Saurabh Vaishnav/ Page 98-116

as Ganesh. Ganesh was always longing for the love of a mother. He felt desperate without it.

Sati too was feeling miserable since the death of her child. After her delivery, she was informed by her father that her child was stillborn. She had accepted that and had started living the life of a Vikarma. She accepted the way how the society ostracized her. It was an ill-fated day that not only did she lose her child, but she also lost her husband. Since that day, Sati was living in false beliefs.

Sati realizes the truth that Daksha, her father, had planned to abandon the deformed son of hers. Tears of anguish, grief and joy pour out of Sati. She was uncontrollable and inconsolable. She lunged forward and embraced her son forgetting all about the deformity. The sentiment and emotions represented here are of pure and eternal love. The suppressed and dormant emotions of motherhood that Sati expected to experience before several years had all come to fruition.

The love represented in this scene is pure, unadulterated, and innocent. It is a pure love shared by a mother and her son. It is an out of the world experience. The union of a long lost son to a mother is represented authentically in the form of Sringara rasa.

"Anandmayi lunged forward and kissed Parvateshwar hard. A deep passionate kiss. Parvateshwar stood stunned, his hands to his side, taking in a pleasure he hadn't ever imagined" (254). Anandmayi was head-over-heels in love with Parvateshwar. Parvateshwar had taken a vow of lifelong celibacy. He wanted to stick to the vow till the end of his life. However Anandmayi's open approach to Parvateshwar was putting him in a conflicting position. 
Towards Excellence: An Indexed, Refereed \& Peer Reviewed Journal of Higher Education / Prof. Jagdish Joshi \& Mr. Saurabh Vaishnav/ Page 98-116

Parvateshwar was slowly and gradually getting attracted to Anandmayi. Anandmayi would also not miss a chance to tempt and seduce him with her sexuality. Parvateshwar was falling in love with Anandmayi but his vow of being a lifelong celibate was hindering him in approaching Anandmayi. The tension and crisis started to take a toll on Parvateshwar. He finally poured his heart out in front of Shiva.

Shiva suggested him that he had followed his vow for umpteen years. Now Parvateshwar did not have anything to prove to anybody. Shiva suggested that Parvateshwar needed to follow his heart. Shiva suggested Parvateshwar to go to Anandmayi and confess his love for her and put an end to the self-caused misery. Parvateshwar approached Anandmayi to confess his love for her.

However it was something that Parvateshwar was doing for the first time in his life. He hesitated, stopped and was uncomfortable to share his inner thoughts to Anandmayi. Anandmayi also allowed Parvateshwar to take his time and patiently waited for him to propose her. As soon as Parvateshwar proposed Anandmayi, she came nearer to him and kissed him passionately. For Parvateshwar, the deep and passionate kiss of Anandmayi was an out-of-the-world experience.

According to Hugh Morris,

The only kiss that counts is the one exchanged by two people who are in love with each other. That is the first essential of the satisfying kiss. For a kiss is really the union of two soul-mates who have come together because they were made for each other. The reason for this is that the kiss is really the introduction to love, true love. The kiss prepares the participants for the love life of the future. It is the foundation, the starting point of sexual love. And it is 
Towards Excellence: An Indexed, Refereed \& Peer Reviewed Journal of Higher Education / Prof. Jagdish Joshi \& Mr. Saurabh Vaishnav/ Page 98-116

for that reason that the manner in which the kiss is performed is so vitally important. (6)

Parvateshwar stood there, unmoved, hands by his side and let Anandmayi take over the situation. Parvateshwar has an ethereal experience. His heart was beating faster and faster. His veins pumping blood as fast as they could all over his body. The scene is dominant with Sringara rasa.

Kartik moved slowly and grabbed the mango. Ganesh embraced his little brother, who immediately got busy, biting strongly into his favourite fruit. He looked up at Ganesh and smiled, whispering between loud slurps. "Wow ... Thank you ... dada." Ganesh smiled again and patted Kartik lightly on his head. (282)

Sati decided that she was going to take both Kali and Ganesh with her to Kashi. Sati was not going to be underwhelmed by what society thought. That was the first instance when Sati introduced Ganesh to his younger brother Kartik. On seeing Ganesh, Kartik was sceptical and apprehensive of approaching him. Sati informed Kartik that Ganesh was his elder brother and Kartik should address Ganesh as 'dada'.

Kartik however was not able shed his inhibitions and he cowered on seeing Ganesh. Ganesh devised a trick to lure out Kartik. He presented a juicy and ripe mango to Kartik. Kartik was surprised to see his favourite fruit from Ganesh. He at once jumped across and took the fruit from the hand of Ganesh. He started eating it, thanked Ganesh and addressed him as 'dada'. Those were little efforts on the part of Sati. She knew how to kindle sentiments and emotions in the mind of little Kartik. 
Towards Excellence: An Indexed, Refereed \& Peer Reviewed Journal of Higher Education / Prof. Jagdish Joshi \& Mr. Saurabh Vaishnav/ Page 98-116

Prophecy Coles writes, "I believe siblings can genuinely love each other, and the games they create amongst themselves may be some of the most precious moments of a remembered childhood" (26). Coles further writes, "Sibling love is crucially important and a failure to be loved by or to love peers and siblings can emotionally distort later relationships" (53).

The underlying rasa during this scene is that of love. Love between brothers as well as love between a mother and her child. There is presence of Sringara rasa.

\section{Karuna Rasa in The Secret of the Nagas}

““I think it doesn't matter if the woman didn't fight to protect herself, No matter what, I should have fought for her"' (142). When Shiva was a young boy, he was traumatized the scene of rape of a woman that he had unknowingly witnessed. Shiva even during his adolescent years was not able to forget the trauma of the incident. He often woke up in the middle of the night from the nightmare of the incident.

Earlier his mother used to console Shiva by saying that the woman had the knife within her reachable limit, still she did not try to strike her attacker with the knife as she was trying her best to survive. Shiva's mother helped Shiva understand that the woman herself knew that the man raping her was too powerful for her, hence she choose to act passively during her rape.

But this consolation was not able to satisfy Shiva. He always felt he should have acted when he witnessed the rape of the woman. The consolations of the mother were not able to satisfy and kindle Shiva. When Shiva's uncle questioned Shiva about what Shiva thought, Shiva said that he should have acted and taken an 
Towards Excellence: An Indexed, Refereed \& Peer Reviewed Journal of Higher Education / Prof. Jagdish Joshi \& Mr. Saurabh Vaishnav/ Page 98-116

initiative during the traumatic ordeal of the woman. Even though the woman was passive, Shiva felt that he should have done something against the rapist.

Maria Miceli and Cristiano Castelfranchi write,

The feeling of guilt is social in that both injury and transgression are social events. Moreover the feeling can imply some social target or addressee, in that the "culprit" can both suffer for the injury inflicted to the "victim" and emphatically share the latter's suffering. However, as we shall see, one can feel guilty despite the absence of a victim. (291)

The helplessness of Shiva was bothering him. He could not forget as well as forgive himself. He hated himself because he chose to do nothing and rather run away from the scene. The woman saw Shiva and pleaded him to help her. However, Shiva was nervous seeing the size of the rapist and he turned around to flee from the incident. His inactions at the time were bothering him and he was not able to overcome the feelings of being gutted. This incident throws light on Karuna rasa on the part of Shiva.

"Shiva cradled Uma in the shelter of his arms, as though trying to give her his strength. "Why didn't you come earlier?" Uma kept crying, inconsolable" (169). Shiva was touring the city of Branga as he was searching answers about the whereabouts of the Nagas. His platoon consisting of Parvateshwar, Drapaku, Bhagirath and Divodas the leader of Branga community were travelling with Shiva.

At the entrance of the Branga kingdom, they were stopped by the security officer, Major Uma was stationed there. Although Divodas and Major Uma were friends, Major Uma was conversing with Divodas in a brazen manner. She was not 
Towards Excellence: An Indexed, Refereed \& Peer Reviewed Journal of Higher Education / Prof. Jagdish Joshi \& Mr. Saurabh Vaishnav/ Page 98-116

ready to allow the passage of Shiva's convoy. Divodas was urging calmly to allow him the passage to Branga, but Major Uma was not in a mood to hear anything.

At that time, Shiva tried to intervene and he was shoved off by Major Uma. Seeing this, Parvateshwar, Drapaku and Bhagirath all drew their swords out. They were enraged to see their lord humiliated by Major Uma. They were about to attack Major Uma when Shiva stopped them. At that time, the cravat that Shiva was covering his throat, came off. Major Uma glanced at the blue throat of Shiva. She was left shocked.

She could not react and was left immobile. She believed the legend that a blue throated foreigner was going to come to the land of Branga and save them from the plague. She was shell-shocked at the appearance of the blue throated Shiva. Major Uma and her husband had just recently lost their only child to plague. Major Uma had conceived after years of trying. She was distraught at the loss of her child which made her bitter and rude.

Julia Bogensperger and Brigitte Lueger-Schuster write,

The loss of a child is one of the most devastating experiences for a parent and is associated with diverse maladaptive developments. Losing a child is recognized as especially disruptive and challenging to the expected order of life events: The young ought to outlive the old. This inconsistency of the loss with the pre-loss worldview brings upon fundamental questions of meaning in life. (1)

As soon as Major Uma saw the blue throat of Shiva, she fell motionless. She started banging her fists on Shiva's chest complaining him of not coming earlier. She 
Towards Excellence: An Indexed, Refereed \& Peer Reviewed Journal of Higher Education / Prof. Jagdish Joshi \& Mr. Saurabh Vaishnav/ Page 98-116

is devastated at the loss of her child and she thought that if the blue throated lord had appeared earlier, her child would have been saved. Her angst against Shiva is completely justified as a mother has just lost her child after years of trying to conceive.

The whole scene is grave and serene. The condition of Major Uma could not be gauged. Her feelings and thoughts were not possible to understand. She was going through an extreme time of pain and misery. The whole scene is laced with Karuna rasa. Divodas who is a witness to the scene and someone who knows Major Uma was full of empathy and pity.

"Isn't it punishment enough that we live alone in this god forsaken palace, with only three servants for company? That the only excitement in our lives is the periodic visits of our brother? How much more do you want to punish us? And will you kindly explain what we are being punished for?" (176)

Sati had reached the Eastern palace secretly. She was intrigued to find out the reason about King Athithigva's secret visits there. She was shocked to see that King Athithigva had arrived there to get his rakhi tied. More shock awaited Sati as she also found out that King Athithigva had come there to get rakhi tied from a Naga woman. The Naga woman was highly deformed.

Sati was soon discovered by one of the attendant who screamed in horror. Sati then came out and confronted King Athithigva about why he was getting his rakhi tied there. King Athithigva revealed that the Naga woman was his sister and he periodically visited her to meet her. Sati then talked about the rule that the Nagas were not supposed to be entertained in their territory and they had to go to the Naga territory. 
Towards Excellence: An Indexed, Refereed \& Peer Reviewed Journal of Higher Education / Prof. Jagdish Joshi \& Mr. Saurabh Vaishnav/ Page 98-116

To this King Athithigva replied that he cannot shun his sister for her deformity. Moreover he promised his late father that he would take care of his sister till the end of his life. Hearing all this, the Naga woman questioned Sati as to what was the reason for such an ill treatment towards her. Just because she was born deformed does not justify her punishment? The Naga woman questioned the reason for her penance as well as her punishment.

Sati had no answers to the questions of the Naga woman. The Naga woman said that due to her deformity, she was ostracized from the society. She was banned to live in the society because of the rules laid out before some thousand years ago. Even her own brother was not able to meet her openly and had to secretly meet her. The Naga woman questioned her predicament and put her apprehension in front of Sati. Sati for the first time realised the aspect from the point of view of a Naga.

Sati felt empathetic and pity towards the Naga woman. She was conditioned to think about Nagas in a negative manner. But for the first time in her life, Sati felt compassionate towards the Nagas. The whole episode is drawn into the light of Karuna rasa. The plight and the suffering of the Nagas were not revealed till now. Their life is full of hardship and suffering. Karuna rasa is poignantly reflected in this scene.

"“Is that why you abandoned me?" Soft tears were rolling down the Naga's cheeks. "Because you couldn't even bear to look at me?"' (235). Sati's army was saved from the attack of the lions by the Nagas. When Sati saw the face of the Naga man, it was heavily deformed. Nowhere had it seemed to be the face of a human being. 
Towards Excellence: An Indexed, Refereed \& Peer Reviewed Journal of Higher Education / Prof. Jagdish Joshi \& Mr. Saurabh Vaishnav/ Page 98-116

Sati's shocking reaction on looking at the face of that man, made the man question her if that was the reason for Sati abandoning him. While asking the question to Sati, the Naga man had tears rolling down from his cheeks. He tried hard to muster up courage to speak but every time he fought hard to control his emotions.

Paul Gilbert writes,

Shame, stigmatization, and ostracism are part of the process by which a group of others decide whom to associate and cooperate with, and whom to exclude, reject, and avoid. They suggest that the domains over which exclusion are most powerfully enacted are those that are evolutionary meaningful and are seen as threats to the social order in some way. Hence, stigmatization is closely linked to signals of disease and physical deformity. (1216)

The Naga man was trying his best to cover up his long time pent up frustration for being a deformed. The Naga man was actually the son of Sati, who long before she had presumed to be still born. The Naga man confronted Sati by asking her that was his deformity the reason to abandon him. The sentiment represented in this scene is of a long lost son vying for the love of his mother.

The Naga had been abandoned and he felt that it was the deformity due to which his mother had abandoned him. He was living his life just to take revenge on his mother for abandoning him. And now when the time arrived, he was bogged 
Towards Excellence: An Indexed, Refereed \& Peer Reviewed Journal of Higher Education / Prof. Jagdish Joshi \& Mr. Saurabh Vaishnav/ Page 98-116

down by emotional sentiments. He desperately wanted to know the answers from his mother for his abandonment. The scene poignantly represents Karuna rasa.

“"I returned to find my father's gurukul destroyed. My mother was sitting outside our house, holding my father's severed head in her lap. She looked like her soul had been burnt alive. Her eyes wide open, blank. A shadow of the woman she had been, broken and brutalized"”' (264).

Parshuram was narrating Shiva, the ordeal that his family had to suffer. Parshuram mentioned that his parents suffered because Parshuram's mother's family members were orthodox. They did not approve the relationship of his parents. They chose a suitable time to avenge his mother for bringing dishonour and ill repute to their family name. They made Parshuram's mother witness the brutal torture of her husband and then they beheaded him in front of her eyes.

Parshuram's mother who was a strong and determined woman was destroyed. Parshuram narrated that when he came back to his house hearing about the tragedy he saw his mother left to ruins. His mother lost all her strength and determination and was just a mere shadow of what she was earlier. The tragedy represented here by Tripathi is pitiable and miserable. There is abject misery and desolation in this part of the novel. Parshuram's mother cuts out as a figure of pity. The scene records the presence of Karuna rasa.

\section{Conclusion}

The research paper sheds the light on the presence of Sringara and Karuna rasas. The relationship between Parvateshwar and Anandmayi is turning to erotic love. The language and communication by Anandmayi has dual-meanings. Shiva's 
Towards Excellence: An Indexed, Refereed \& Peer Reviewed Journal of Higher Education / Prof. Jagdish Joshi \& Mr. Saurabh Vaishnav/ Page 98-116

behaviour too reflects the presence of Sringara rasa during his interaction with Sati.

Sati is pregnant and Shiva showers love, attention, comfort and warmth to her. The camaraderie between Kartik and Ganesh replicates Sringara rasa.

Shiva's apprehensions regarding his failure in saving the woman from getting raped echo the presence of Karuna rasa. He witnessed the disturbing event during his childhood and even in his mature age, he is unable to forget the traumatic incident. Uma is inconsolable as she lost her baby after years of trying to conceive. She had heard about the legend of Shiva and when she met Shiva, she cried profusely and regretting that he arrived late after the death of her baby. Sati experiences the pain and suffering that King Athithigva's sisters were going through due to their deformity. The Naga man poignantly questions Sati the reason for her abandoning him as her child. The situations signify the presence of Karuna rasa. 


\section{Works Cited}

Bogensperger, Julia, and Brigitte Lueger-Schuster. "Losing a Child: Finding Meaning in Bereavement." European Journal of Psychotraumatology, vol. 5, no. 1, 31 Mar. 2014, doi:10.3402/ejpt.v5.22910.

Coles, Prophecy. The Importance of Sibling Relationships in Psychoanalysis. $\mathrm{H}$. Karnac (Books) Ltd., 2003.

Gilbert, Paul. "Evolution, Social Roles, and the Differences in Shame and Guilt." Social Research: An International Quarterly, vol. 70, no. 4, 2003, pp. 12051230.

Meston, Cindy M., and Lucia F. O'Sullivan. "Such a Tease: Intentional Sexual Provocation within Heterosexual Interactions." Archives of Sexual Behavior, vol. 36, no. 4, June 2007, pp. 531-542., doi:10.1007/s10508-006-9167-7.

Miceli, Maria, and Cristiano Castelfranchi. "How to Silence Ones Conscience: Cognitive Defenses Against the Feeling of Guilt." Journal for the Theory of Social Behaviour, vol. 28, no. 3, 1998, pp. 287-318., doi:10.1111/14685914.00076.

Morris, Hugh. The Art of Kissing. Ruas, 2009, pp. 6.

Sternberg, Robert J. "A Triangular Theory of Love.” Psychological Review, vol. 93, no. 2, 1986, pp. 119-135.

"The Psychology Behind Love and Romance." South University, 23 Aug. 2016,

www.southuniversity.edu/news-and-blogs/2016/08/the-psychology-behind-love-andromance- 70700 .

Tripathi, Amish. The Secret of the Nagas. Westland Itd., 2011.

\section{Saurabh Vaishnav}

Assistant Professor

St. Xavier's College (Autonomous), Ahmedabad

\&

Prof. Jagdish S. Joshi

Professor and Director

UGC - Human Resource Development Centre (UGC-ASC)

Gujarat University, Ahmedabad 